\title{
GIS-Approach to Estimate Ground Transport Accessibility of Forest Resources (Case Study: Novosibirsk Region, Siberian Federal District, Russia)
}

Ekaterina Podolskaia, Dmitriy Ershov, Konstantin Kovganko

Laboratory of Forest Ecosystems Monitoring, Center for Forest Ecology and Productivity, Russian Academy of Sciences, Moscow, Russia

Email: ekaterina.podolskaia@gmail.com

How to cite this paper: Podolskaia, E., Ershov, D. and Kovganko, K. (2020) GIS-Approach to Estimate Ground Transport Accessibility of Forest Resources (Case Study: Novosibirsk Region, Siberian Federal District, Russia). Journal of Geographic Information System, 12, 451-469. https://doi.org/10.4236/jgis.2020.125027

Received: August 20, 2020

Accepted: October 11, 2020

Published: October 14, 2020

Copyright $\odot 2020$ by author(s) and Scientific Research Publishing Inc. This work is licensed under the Creative Commons Attribution International License (CC BY 4.0).

http://creativecommons.org/licenses/by/4.0/

(c) (i) Open Access

\begin{abstract}
In the big forest countries, there is an actual challenge of accessing the forests for their resources, operational wildfire management, and economic estimations for various purposes. In Russia, there are two ways to access the forests: by air and by ground means. The first way is quite expensive for any country. The second one is less expensive but has the spatial planning challenges to create access routes by existing public roads and forest glades. Regional authorities and firefighting departments are paying attention to the access by ground means, but there is a certain room to improve their management and cooperation methods on a limited budget. These tasks could be solved by GIS-technologies in a more operational manner to automate the routes' construction especially during the fire season. We used combined geoinformation technology (developed previously) and satellite product, namely vegetation map from Moderate Resolution Imaging Spectroradiometer (MODIS) to estimate how accessible any forest area is when moving by public roads and forest glades from a fire station as a starting point. These stations are the main centers to fight the forest fires within the territory of ground protection zones in Russia and we have considered them as the logistic centers to manage the forest resources also. Transport model was created in two variants: no-barriers and barriers-based (forestries). By using these two models we have shown two different scenarios of action. The key area was Novosibirsk Region located in the Siberian Federal District, Russia. We have created a series of maps to show the transport accessibility of forest areas from the fire stations. Estimation of "located" pixels or forest areas accessible from the fire stations for the key area is about $66 \%-83 \%$; the most accessible forest type is
\end{abstract}


mixed forests. The number of inaccessible pixels has been increased by more than two times in barriers scenario. Technology can be used for different thematic data sources and domains like ecology or economy.

\section{Keywords}

Ground Accessibility, GIS, Barriers, Forest Resources, Forestry, Fire Station, MODIS

\section{Introduction}

The term "transport accessibility" is used in a wide variety of geographical and economic studies. A significant number of works written by international scientific community [1]-[15] is devoted to the topic of transport accessibility of forests, the intensity of forestry and forest use. The choice of accessibility assessment parameters (location criteria) is always a geographical, metric, and thematic issue that needs to be addressed in the context of a given region. Accessibility is one of the environmental influence factors [16] when there is a need to make a tactical assignment relative to the roads. Accessibility certainly limits the use of resources, natural of human-produced ones.

There are some global interdisciplinary projects describing transport accessibility, namely ground access from the cities and roadless areas. We have found cartographic products of some transport projects [17] [18] [19]. For instance, paper [17] presents a global map of roadless areas and their conservation status. Another example is a raster showing travel time to the nearest city of 50,000 or more people in the year 2000 from the study [18].

The organization of forest cover complex monitoring and forest protection in the modern economic conditions of Russia (as well as in any other forestry country) has certain challenges. As Russian experts note in their works, for example [20] [21], it is important to optimize the allocation of logistic forest centers to protect forests from the wildfires and to manage the logging operations.

Nowadays scenarious and different strategies to plan the move are of constant research interest and common in the industrial practice of transport modeling, [https://gisforthought.com/forth-road-bridge-closure-impact-on-drive-times/].

Modeling with barriers for a geospatial domain is being implemented with the functionality and data of modern GIS for different operational conditions and collaborations.

We continue the GIS-study on the forest fire protection [22] [23] [24] [25] [26]. The objective of the present research is to apply our previously developed GIS-methodology, described in the paper [24], to estimate accessibility of forest resources taking into account fire stations' responsibility areas with no-barriers/ barriers modeling. To archive this objective, we have formulated a set of tasks: 1) definition of no-barriers and barriers scenarios of operational access to the forest 
pixels (forest resources); 2) mapping of scenarios, analysis of their outputs for the key area within the Siberian Federal District (FD); 3) using of scenarios to evaluate the transport location of fire stations, and 4) an analysis of transport accessibility by type of forest vegetation. To solve the tasks mentioned above we have analyzed actual Russian forest regulation documents, namely: a) the principles of extinguishing forest fires within the boundaries of forest areas, b) the relationship of forest areas and fire station in terms of their administrative responsibility.

"A barrier" in the present GIS-research means a boundary of forest or administrative division, it is a polyline to specify the priorities to promptly manage the logistical efforts to access the forest resources within the fire stations' areas of responsibility.

\section{Data and Methodology}

Figure 1 presents a general methodology with the operations and the spatial data involved. The idea was to combine vector (roads, forest firefighting centers or stations and forest divisions) and raster (forest vegetation) data and produce the scenarios of the ground move considering forest divisions as barriers. The first step is to create the access routes in case of barriers presence/absence. At the mapping step, we visualize the routes, calculate and analyze routes' time, length, and speed. The final step consists of transport accessibility mapping showing how far the forest areas (pixels) are located from the fire stations.

We have used the following data: 1) a transport model of the FD created for the road network (public roads and forest glades) derived from Former Soviet Union topographic maps of 1:200,000 and updated based on the Open Street Map or OSM web service [https://www.openstreetmap.org] road map, 2) raster vegetation map compiled from the MODIS data of $230 \mathrm{~m}$ spatial resolution [27] [28], and 3) vector layers of fire stations and forest boundaries, as well as administrative divisions by districts [29].

Data on the road network and fire stations were combined with a vegetation raster. Each "forest" pixel (a pixel with any type of forest) is considered as a point (location) in the region. Its accessibility has to be evaluated by three parameters, namely: time, distance, and speed of accessing by special transport (any heavy vehicle like logging truck or fire brigade truck, etc.) according to the defined speed parameters for different road coverage types, Table 1 from the paper [24]. The result is a map showing time, distance, and speed of movement from the nearest station to the forest areas (vegetation map pixels), which, in turn, is the basis to produce a map of forest areas' accessibility.

Forest roads play an important role in the forest firefighting infrastructure of every forest country, examples (besides Russia) are Canada, France, Bulgaria, Turkey, Finland, Spain and Italy and other countries, an analysis of roads planning, construction and maintenance is done in some recent publications [30] [31] [32]. We assume that any accessibility analysis for the forest resources should include data on the forest roads. 


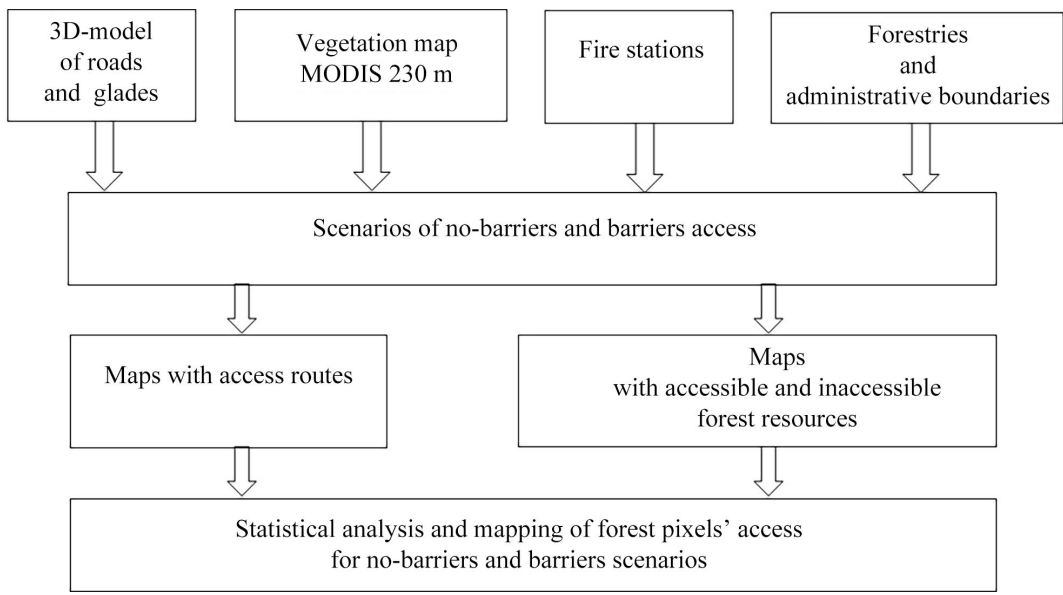

Figure 1. General scheme of methodology.

Table 1. Characteristics of no-barriers and barriers datasets.

\begin{tabular}{llll}
\hline & Scenario & $\begin{array}{l}\text { Fire stations } \\
\text { I type }\end{array}$ & $\begin{array}{l}\text { Fire stations } \\
\text { II type }\end{array}$ \\
\hline & No-barriers & $\begin{array}{l}246,584 \text { pixels/ } \\
13,069 \mathrm{~km}^{2}\end{array}$ & $\begin{array}{l}246,584 \text { pixels/ } \\
13,069 \mathrm{~km}^{2}\end{array}$ \\
$\begin{array}{l}\text { Total number of accessible } \\
\text { pixels }\end{array}$ & Barriers & $\begin{array}{l}195,251 \text { pixels/ } \\
10,348 \mathrm{~km}^{2}\end{array}$ & $\begin{array}{l}199,211 \text { pixels/ } \\
10,558 \mathrm{~km}^{2}\end{array}$ \\
& No-barriers & $83.1 \%$ & $83.1 \%$ \\
$\begin{array}{l}\text { Accessible forest resources relative } \\
\text { to the Region's forest coverage }\end{array}$ & Barriers & $65.8 \%$ & $67.1 \%$ \\
\hline
\end{tabular}

The main purpose of fire stations (PKHS, in Russian forest terminology or fire-chemical stations in English exact translation) is to prevent, to detect, and to limit the spread of forest fires in a timely manner. They are organized as forest fire protection network at the regional level in forest enterprises, educational forestries, national parks and state nature reserves. Fire stations are equipped by special firefighting equipment and trained staff [33]. There are three types of fire stations. The first two ones are located at the forestry level. They differ in terms of fire brigades' number and fire-fighting equipment and managed by the forestry director. Their responsibility area is a sub-forestry (type I) and a forestry (type II). In exceptional cases, resources can be transferred from one forestry to another one (for example, then there are many fires in a neighboring forestry with a limited number of fire brigades and equipment to fight them). Stations of third type are organized at the administrative district level with permanent staff and large reserve of technical equipment. This station is assigned to the forest department of the region. The purpose of this type of station is to fight fires in an emergency fire hazard.

Chosen key area (Novosibirsk Region) is located within the Siberian FD of Russian Federation (Figure 2). The region is characterized by mixed broadleaf-coniferous forests and non-forest vegetation and an intensive human economic activity [21]. 


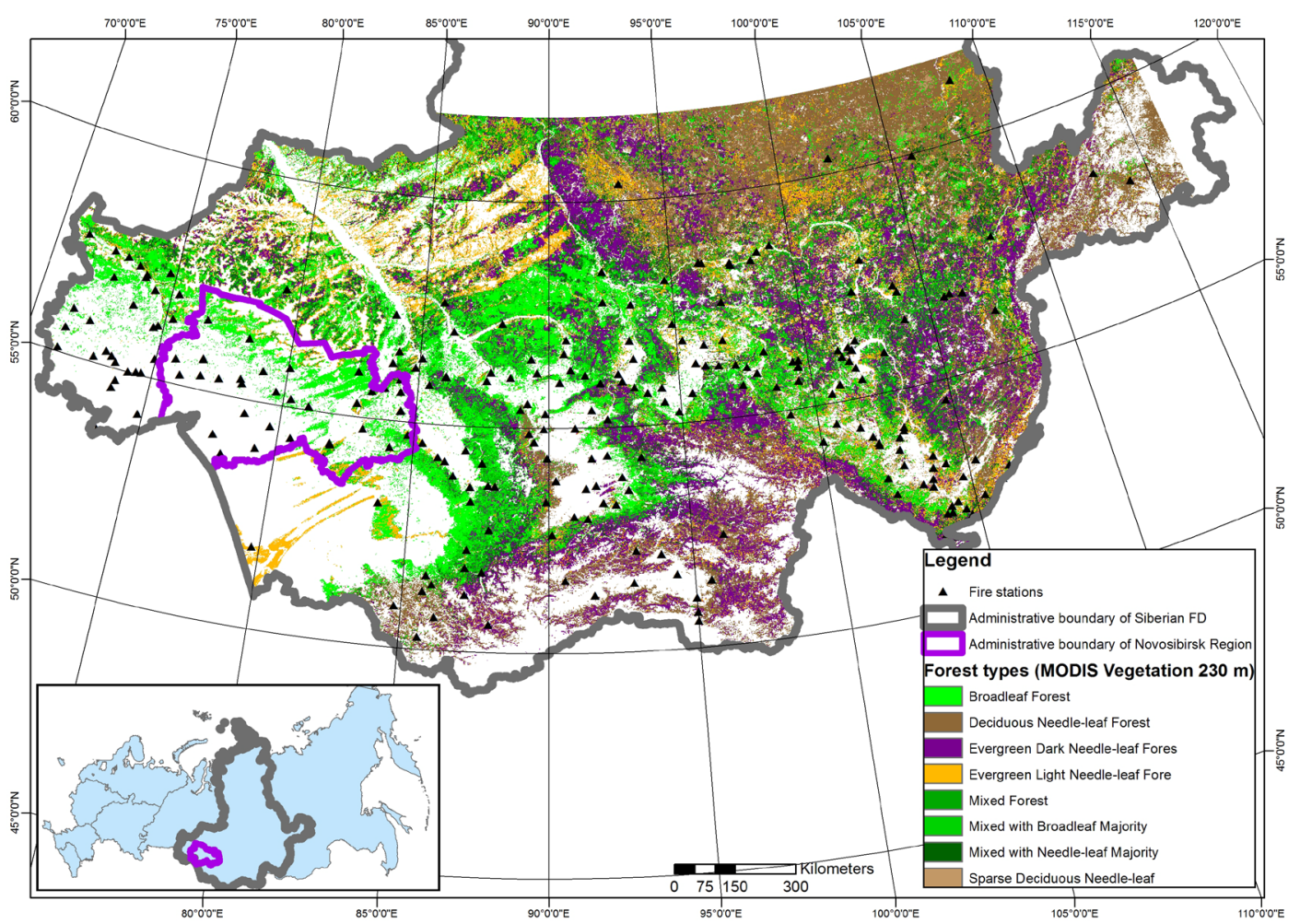

(a)

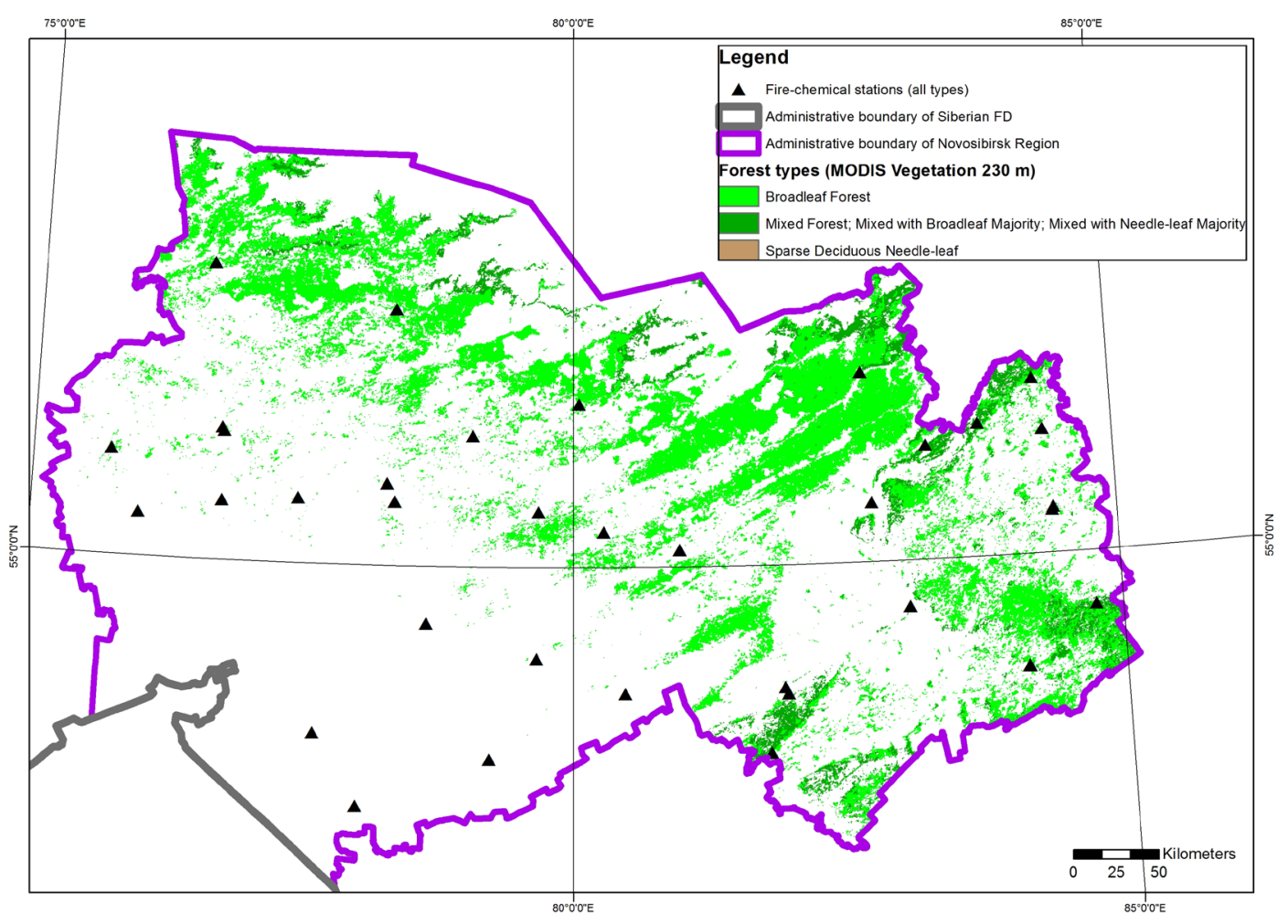

(b)

Figure 2. Forests in the Central part of Siberian FD (a) and within Novosibirsk Region (b). Both maps are presented in the conical azimuthal projection. 
Forest areas or forestries are the important assets [34] and main territorial protection and reproduction units in the forest industry in Russia. Forestry geometry depends on the administrative division of the region, and in Russia they often follow the boundaries of administrative areas (or raion, in Russian classification).

So, a GIS-methodology to navigate a vehicle from a fire station to the forest resources (pixels of vegetation map) with no-barrier and barrier scenarios includes:

- Creation of no-barriers/barriers datasets and their cartographic representations: data quality control for geometry and attributes, updates with combination of OSM data;

- Mapping of scenarios: creation of routes maps showing access time, length and speed of vehicle's move;

- Evaluation of fire stations' transport location for two scenarios: analysis of routes within the 3 hours' time limit;

- Statistics calculation for the routes' scenarios to access the forest resources: mean, standard deviation and median;

- Analysis and mapping of forest pixels' regional access for no-barriers and barriers scenarios: definition of accessible and inaccessibles resources.

\section{Results}

\subsection{Scenarios of No-Barriers and Barriers Access to the Forests}

We consider an access scenario as an operational activity or a technical way to navigate a forest management unit (could be a fire brigade or timber truck, or another special vehicle) when there is a need to reach the forest resources for any reason. Vehicle accesses a forest area by grounds means, public roads and forest glades, starting its move from the fire station. We applied two scenarios: no-barriers and barriers scenario, created routes were classified by access time, length and speed. Barriers are the forest (forestries) division with the boundaries of administrative division in the Siberian FD. Geometrically they are polylines used to construct a road network in the Network Analyst of ArcGIS ESRI. As a result of road network modeling, we obtained route maps with distance, speed and travel time from the nearest station to each forest area without restrictions and with restrictions. Both scenarios were to be used to show any differences in accessing to the forest resources and to evaluate the importance/necessity of taking into account the borders.

\subsection{Cartographic Representation of No-Barriers and Barriers Datasets}

There are two datasets produced from the initial data (Table 1). We've got four raster layers per each scenario: "located" pixels to the fire stations (forest resources accessible from the stations) and "created routes" (routes from the fire station to the forest pixel) for the stations of type I and stations of types I and II together. There are about 300,000 records in the dataset of key area. Forests cov- 
er about $15,726 \mathrm{~km}^{2}$ (number of all forest pixels is 296,729 ) out of $177,756 \mathrm{~km}^{2}$ (https://www.nso.ru/page/2264). Forested area of Novosibirsk Region is about $9 \%$ from the whole forest region's coverage. As we can see from Table 1, there is no significant quantitative difference ( $83 \%$ and $66 \%-67 \%$ from all pixels within the region for no-barriers and barriers consequently) between two scenarious of forest accessibility. Number of pixels was converted to the area units taking into account the size of MODIS pixel. Data from Table 1 mapped, presented in the Mapping Section 3.3.

\subsection{Mapping of Scenarios}

Scenario with no-barriers (no-boundaries): It is the simplest scenario when a forest place can be reachable from the nearest fire station by ground means by free move without any boundaries of responsibility (Figure 2(b)).

Scenario with barriers (boundaries): For the barriers, we followed the Russian rules in the forest domain [34]. We use the geometries of forestries and administrative division to make a polyline mask of barriers (Figure 3 ) which has at least one fire station per unit for the majority of cases.

The output results are the raster layers for no-barriers and barriers scenarios in GIS environment, they could be viewed in Desktop or WEB-interface. For the given key area and given configuration of stations our preliminary tests with stations I (30 stations) and I and II types (37 stations) separately have shown that there is no significant difference in the access routes' results (presence or absence of routes, numbers were put into Table 2). So, for the visual results, we have decided to show a set of maps for both types of stations.

Below we present a set of maps for no-Barriers (a) and Barriers (b) scenarios of route network modeling for the fire stations classified by time access (Figure 4 ), route length (Figure 5) and averaged vehicle speed on the route (Figure 6).

\subsection{Using of Scenarios to Evaluate Fire Stations' Transport Location}

Figure 7 presents the maps of accessibility within 3 hours only, which is a critical time condition for the forest fire management in Russia [33]. We think that this time limit is applicable and reasonable for the forest resources management also. As we can see from Figure 7, for both scenarios almost all the stations (both types, I and II) were used as logistical points to start the move to the forest resources. Common practice on the forest industry in Russia is to place the fire stations within the settlements to facilitate the logistics.

Geometrically both scenarios have some common features in the central part of the key area. The difference between scenarios is visible in the eastern part where there are no stations and forestries have complex geometry (for barriers scenario).

\subsection{Transport Accessibility by Type of Forest Vegetation}

For the generalization purposes, types of forest vegetation from MODIS classifi- 
cation have been regrouped into 4 categories (Table 2), these categories cover the whole Novosibirsk region, namely: evergreen light needle-leaf forest, mixed forest (mixed with needle-leaf majority, mixed with broadleaf majority and mixed forest), and sparse deciduous needle-leaf. Absolute values of forest vegetation pixels in the Table have been calculated per each scenario, relative (in \%) are relative to the number of totally accessible pixels, given for reference in the same Table. Forest types were grouped in Table 2 in descending order by their values.

Table 2. Characteristics of scenarios by types of forest vegetation in Novosibirsk Region.

\begin{tabular}{cccc}
\hline $\begin{array}{c}\text { Forest } \\
\text { vegetation }\end{array}$ & Scenario & $\begin{array}{c}\text { Fire stations } \\
\text { I type }\end{array}$ & $\begin{array}{c}\text { Fire stations } \\
\text { II type }\end{array}$ \\
Mixed forests & No-barriers & $198,236(80.4 \%)$ & $198,236(80.4 \%)$ \\
broadleaf forest & No-barriers & $155,879(79.8 \%)$ & $158,350(79.5 \%)$ \\
Sparse deciduous & barriers & $31,320(12.7 \%)$ & $31,320(12.7 \%)$ \\
needle-leaf & No-barriers & $25,426(13.0 \%)$ & $26,809(13.4 \%)$ \\
Evergreen light & barriers & $13,442(5.4 \%)$ & $13,541(5.5 \%)$ \\
needle-leaf forest & No-barriers & $16,350(8.4 \%)$ & $16,350(8.2 \%)$ \\
& barriers & $679(0.3 \%)$ & $679(0.3 \%)$ \\
\hline
\end{tabular}

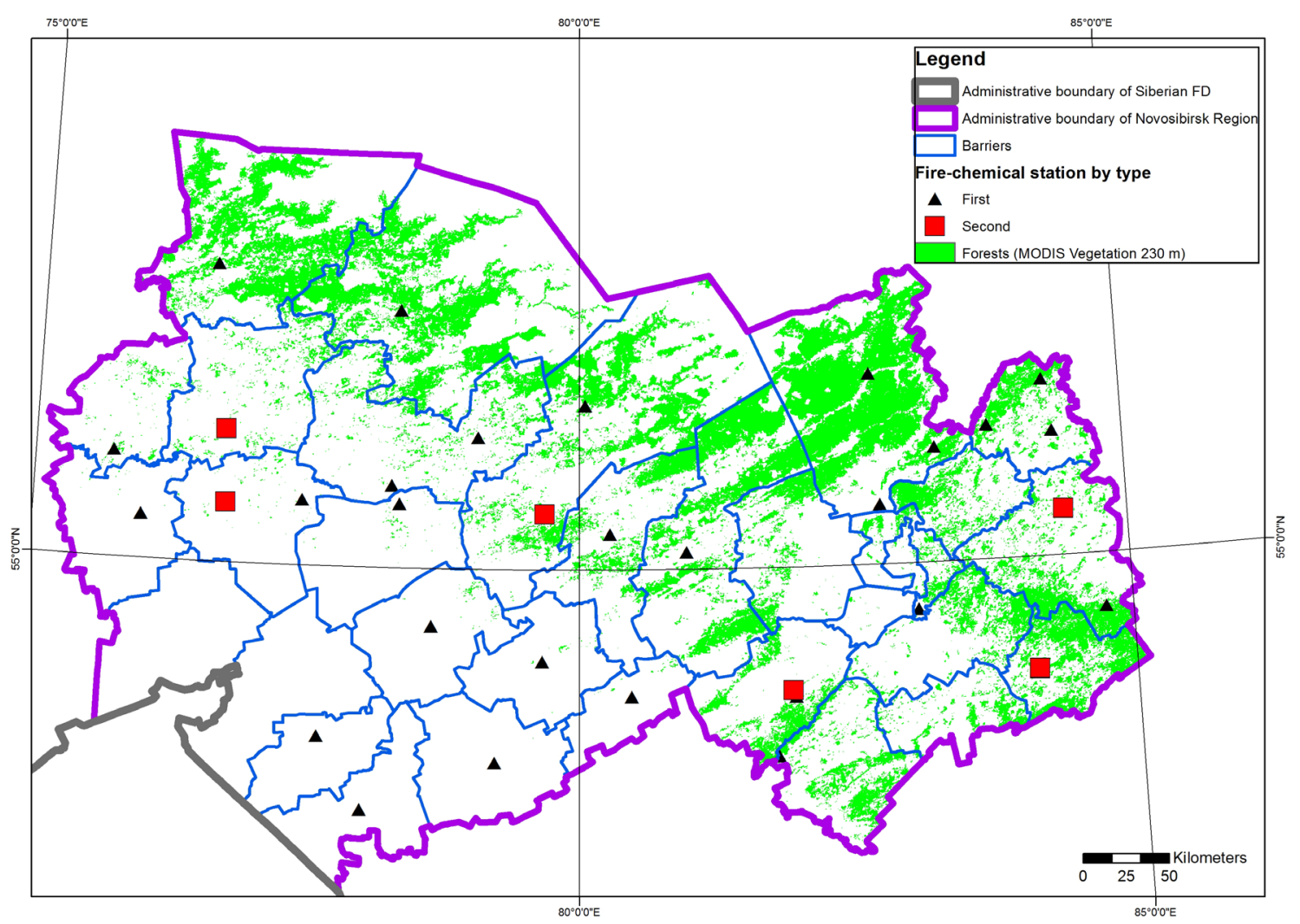

Figure 3. Novosibirsk region: fire stations and polyline mask of barriers. 


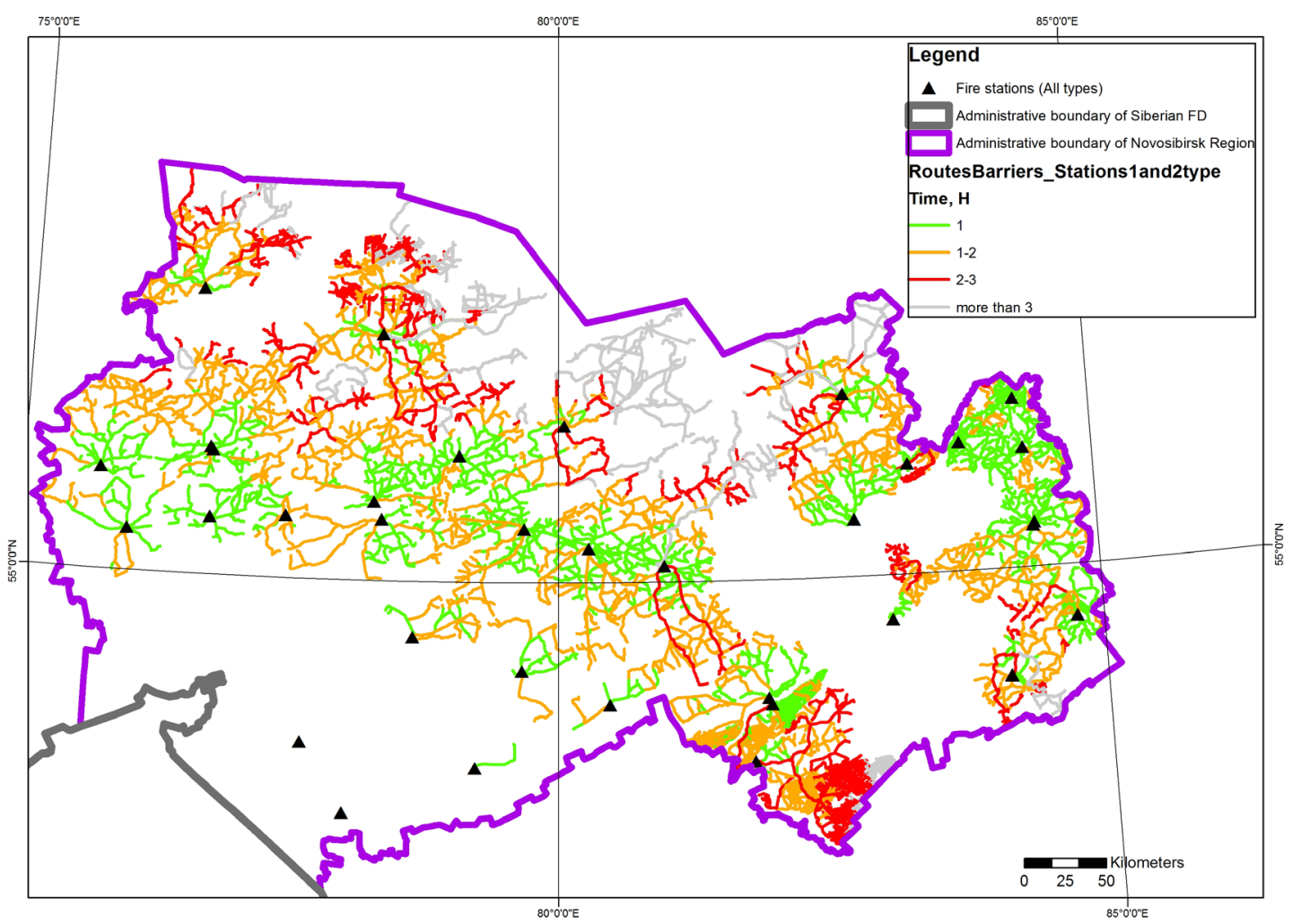

(a)

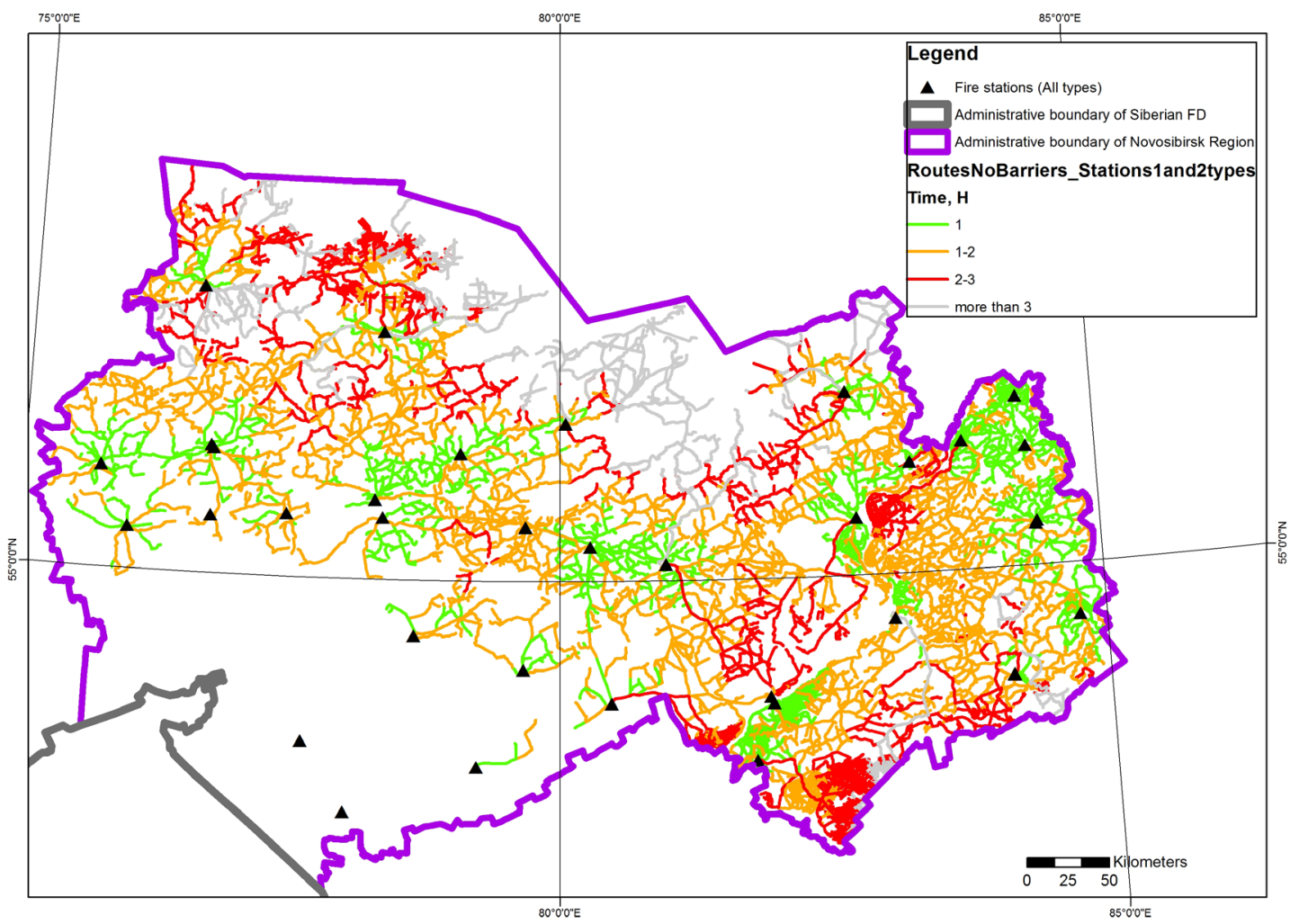

(b)

Figure 4. Routes to the forest resources classified by access time, in hours. 


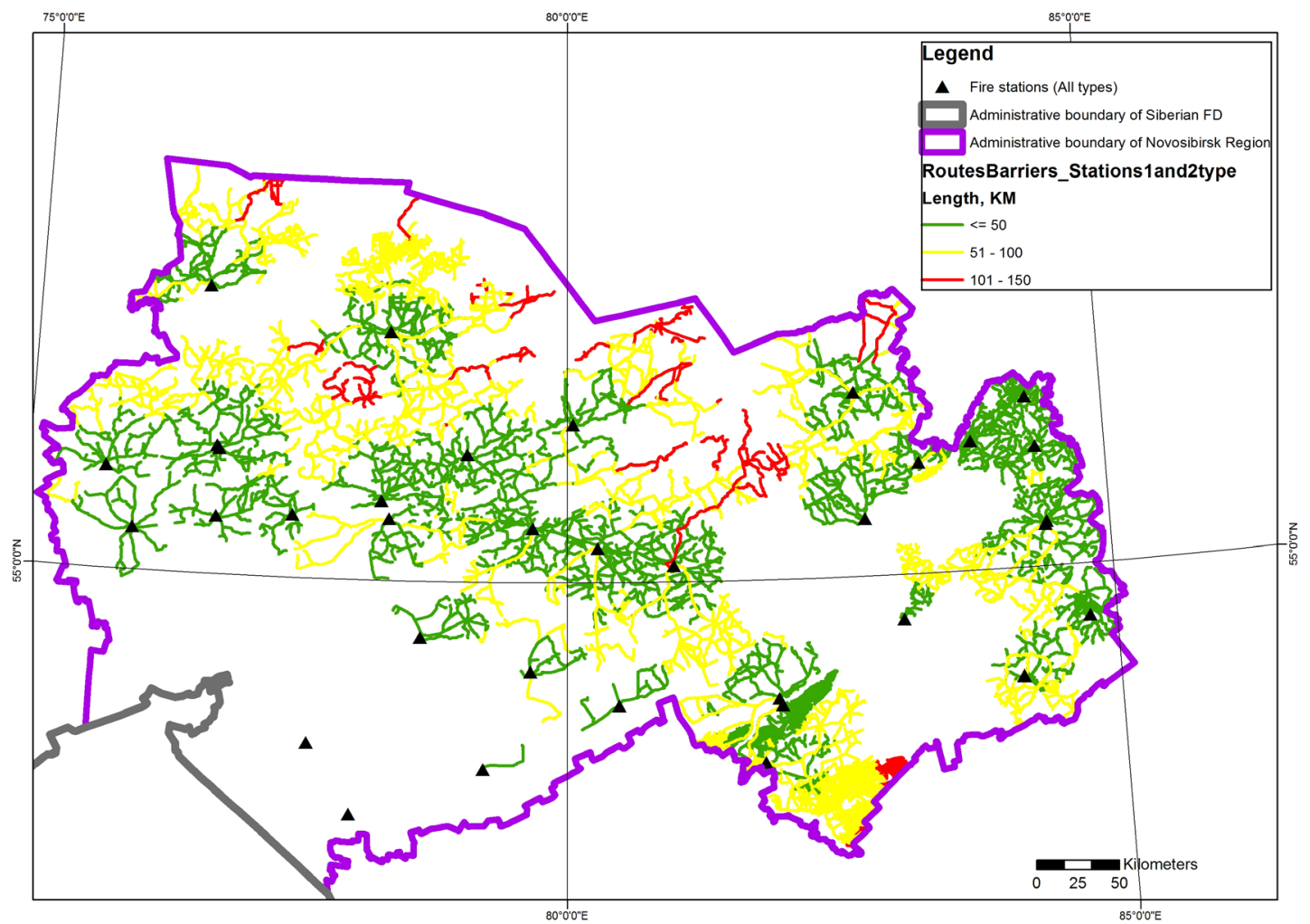

(a)

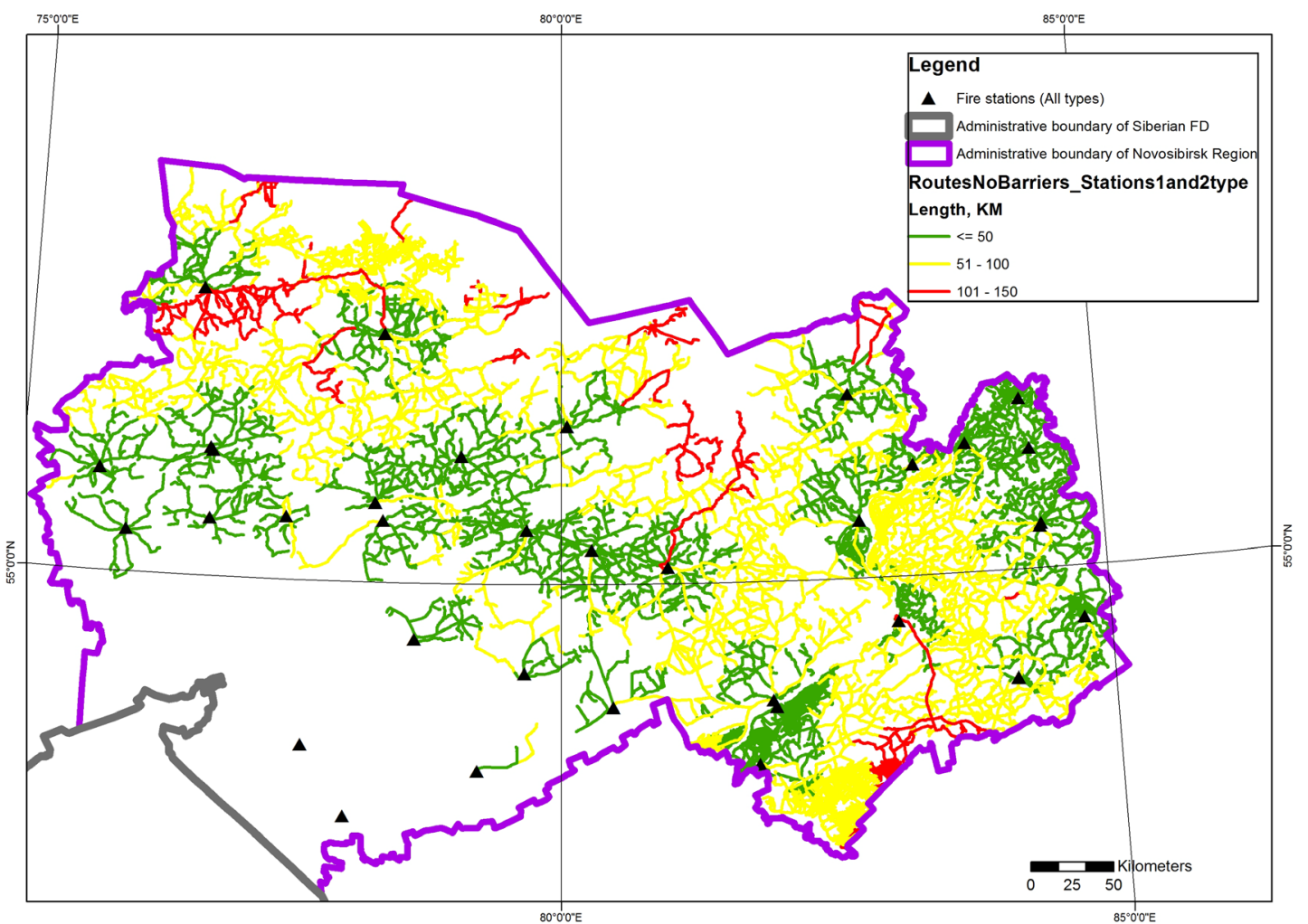

(b)

Figure 5. Routes to the forest resources classified by length, kilometers. 


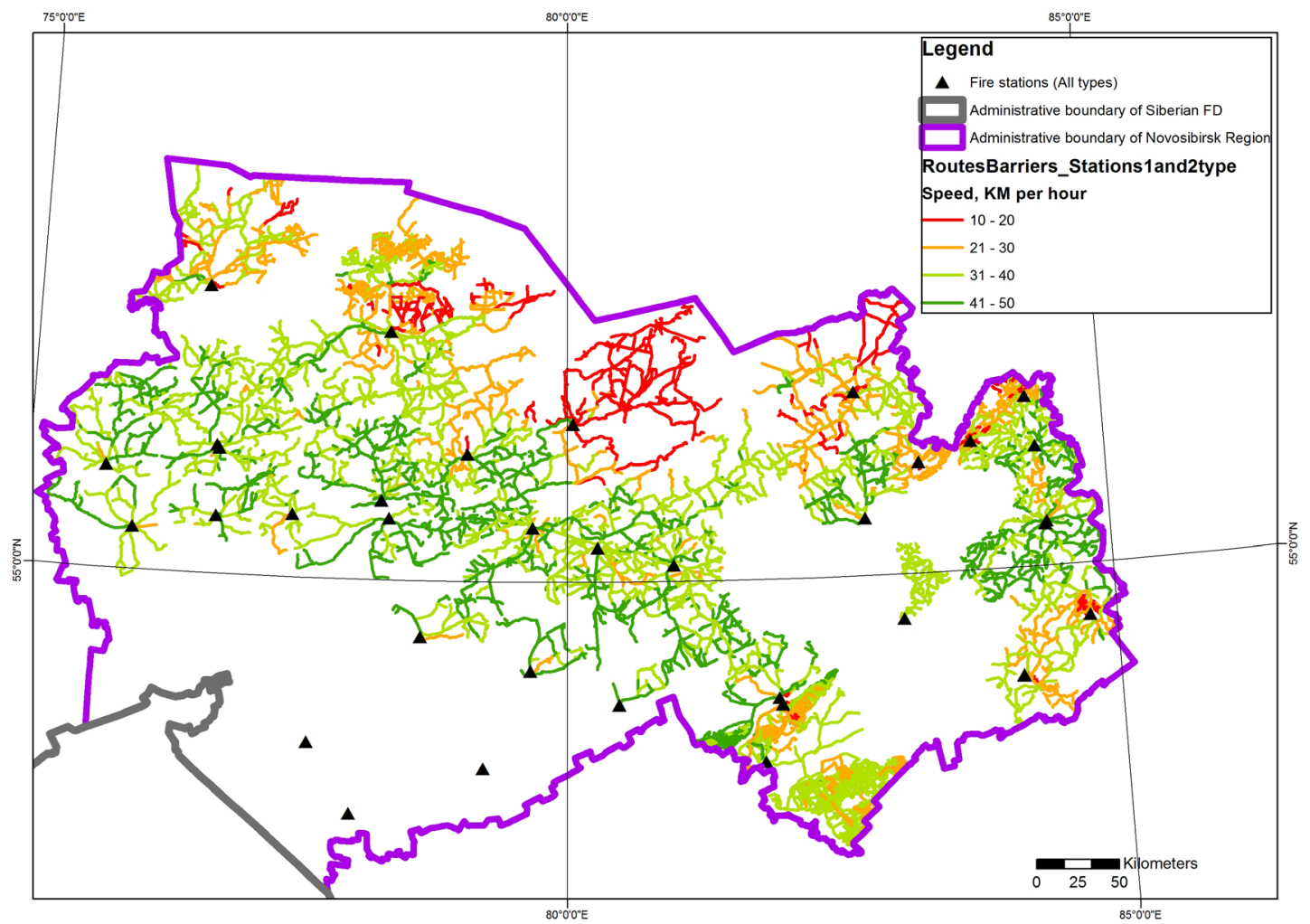

(a)

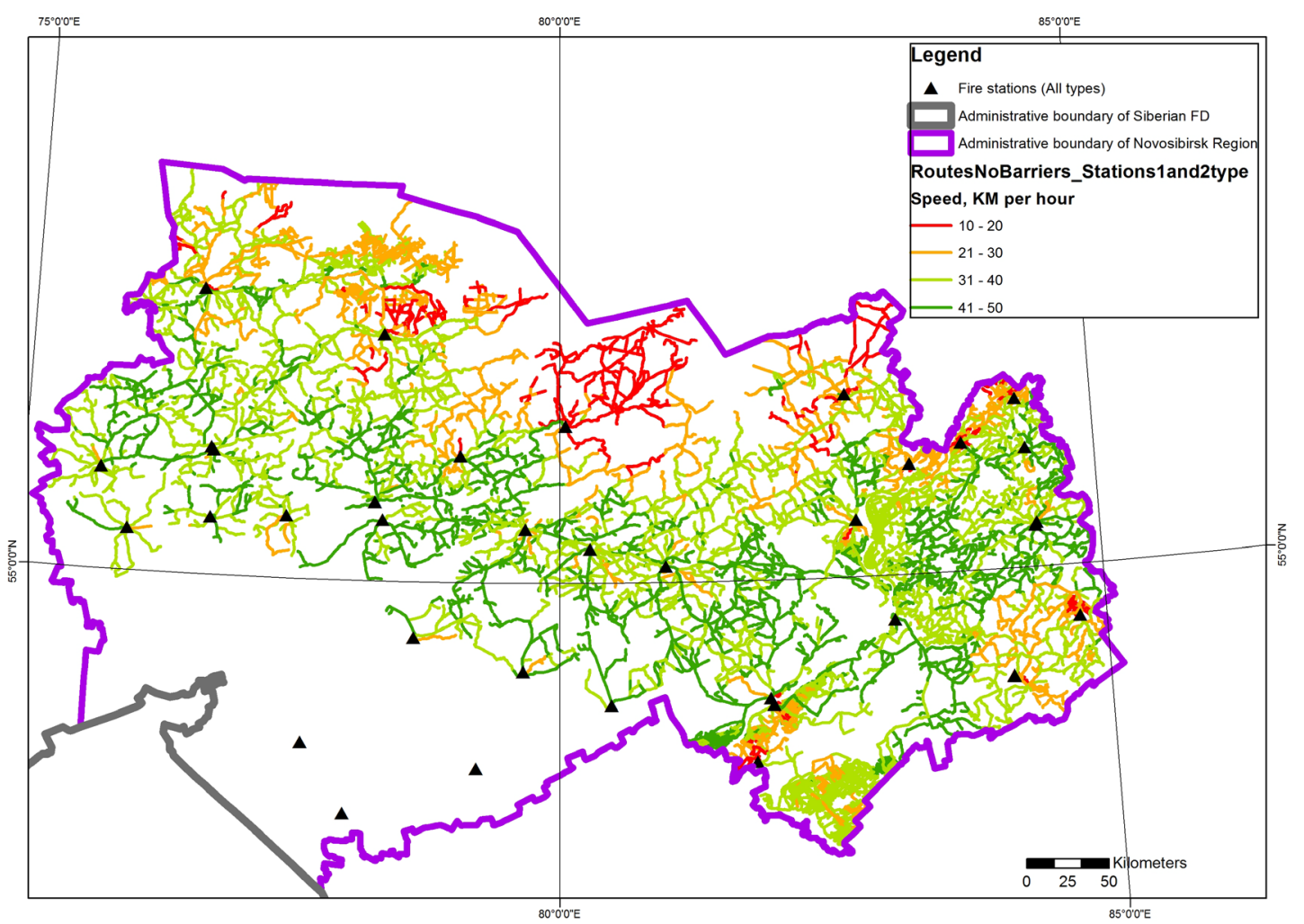

(b)

Figure 6. Routes to the forest resources classified by speed, kilometers per hour. 


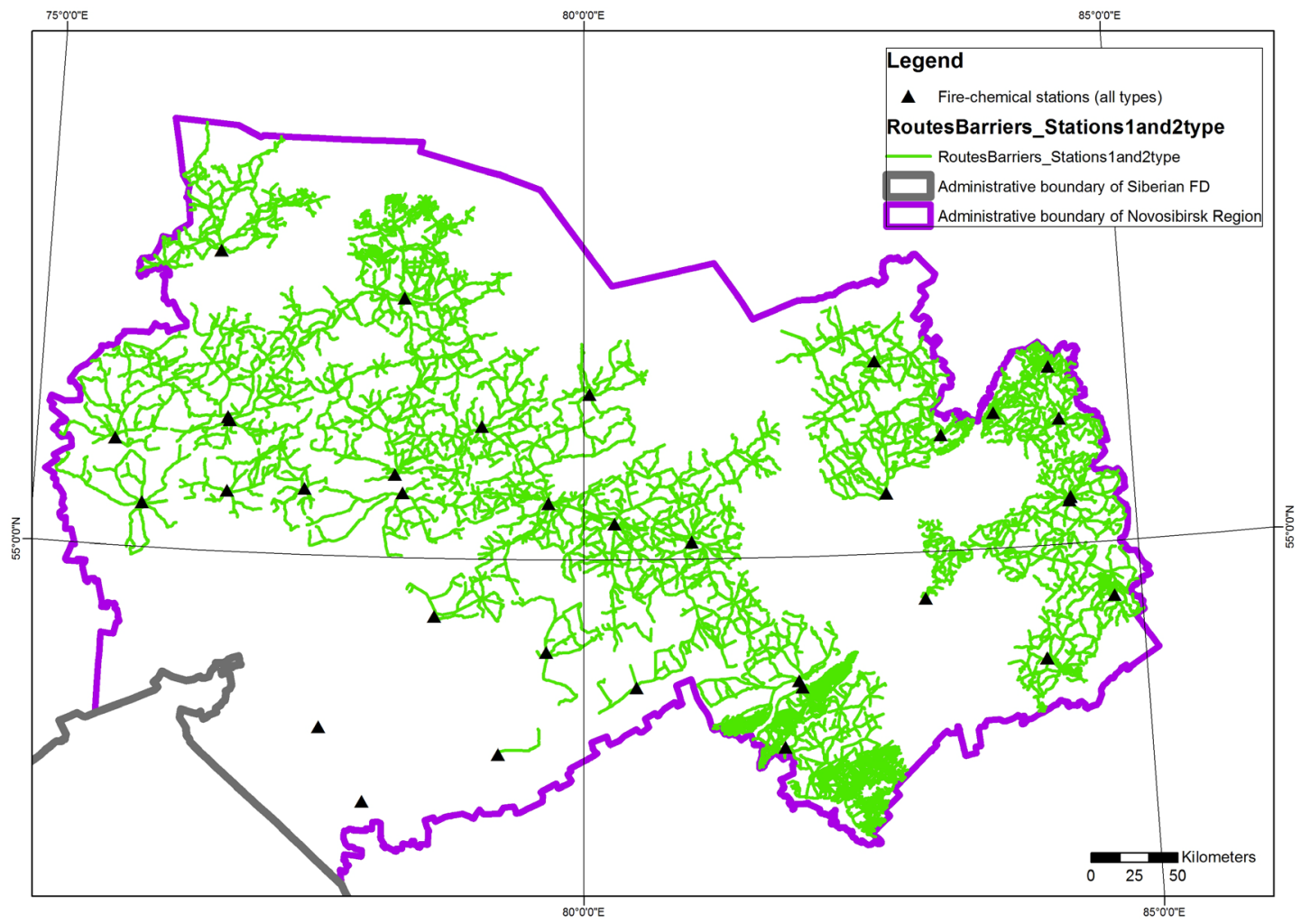

(a)

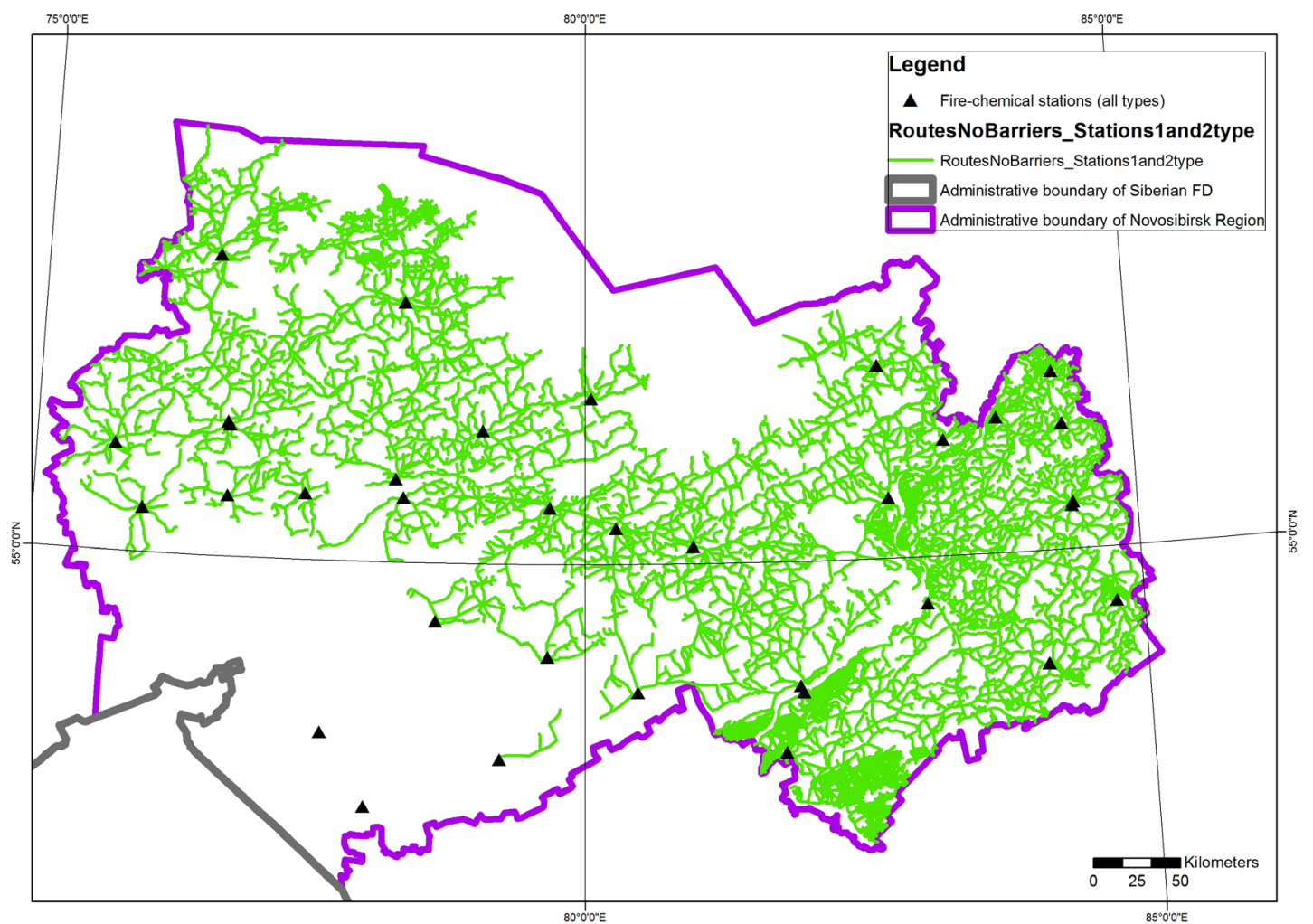

(b)

Figure 7. Routes within 3 hours of access relative to the fire stations: (a) no-barriers, and (b) barriers scenario. 
As we can see from the number in Table 2, mixed forests are the most accessible ones among other types, evergreen light needle-leaf forests are the less accessible. The values are naturally in line with the fact that mixed forests dominate within key area (Figure 2(b)).

There is no difference (except broadleaf forests with barriers with $0.4 \%$, sparse deciduous needle-leaf forests no-barriers with $0.1 \%$, sparse deciduous needle-leaf forests with-barriers with $0.2 \%$ and mixed forests with barriers with $0.4 \%$ ) between the numbers for two variants of scenarios: stations of I type or stations of I and II types.

\subsection{Analysis and Mapping of Forest Pixels' Access for the No-Barriers and Barriers Scenarios}

We have calculated the statistics for the routes' scenarios to access the forest resources (Table 3). As it is seen in this Table, medium speed for both scenarios is about $31-32 \mathrm{~km}$ per hour, with the length $53-56 \mathrm{~km}$ and of about 2 hours of drive. In Table 3 , mean is a mean value, $\mathrm{SD}$ - standard deviation, and median in a median value.

In Table 4 for comparison purposes, the number of pixels has been normalized to the area of forest pixels. As we can see from this Table, in all access time categories there is a decrease in pixels from 2.2 (more than three) to $7.7 \%$ (1 - 2 hours). But the biggest change is seen for the forest pixels that are no longer accessible in barriers scenario (17.3\%).

For the final analysis of present research, we have summarized the differences in Table 4 (number of pixels/\%) and produced the rasterized maps of forest resources accessibility in the Novosibirsk Region (Figure 8).

Based on the results of the study time plays an important role (Table 4): for both scenarios approximaly $1 / 5$ of forests is accessible within 1 hour, $11 \%-14 \%$ of forests are accessible within more than 3 hours, and up to approximately $1 / 3$ of forests (barriers scenario) are inaccessible.

\section{Discussions}

Summary of the paper is the maps presented on Figure 8 to characterize ground access to the forests in the regions of the Central Siberia of Russia (example of Novosibirsk Region) by public roads and forest glades. We can state that $65 \%$ $83 \%$ of forest pixels of Novosibirsk Region are accessible by public roads and forest glades (Table 1).

Table 3 is one of the key outputs for the analysis. Statistically by using mean, median, and standard deviation we have shown that forests are accessible within 3 hours, speed is about $32-33 \mathrm{~km}$ per hour (mean and median are practically equal) with standard deviation of about $7 \mathrm{~km}$ per hour. Length of access routes varies within $53-56 \mathrm{~km}$ with the deviation of $24 \mathrm{~km}$. Fire stations of first level (type) cover the operational access needs for the forests $(65 \%$ of the forested areas) within three hours, under condition that no more than two fires occur per day within the boundaries of one forestry. Contribution of second level's fire sta- 
tions is insignificant due to the fact that their share is small compared to the number of stations of the first level.

Table 3. Accessible forest pixels for no-barriers and barriers scenarios.

\begin{tabular}{|c|c|c|c|}
\hline Value & $\begin{array}{c}\text { Fire } \\
\text { stations I type }\end{array}$ & $\begin{array}{c}\text { Fire } \\
\text { stations II type }\end{array}$ & $\begin{array}{c}\text { Mean } \\
\text { for scenario }\end{array}$ \\
\hline \multicolumn{4}{|c|}{ No barriers } \\
\hline Mean length, km & 56.17 & 56.17 & 56.17 \\
\hline Mean time, hours & 1.99 & 1.99 & 1.99 \\
\hline Mean speed, km per hour & 32.28 & 32.28 & 32.28 \\
\hline SD length, $\mathrm{km}$ & 24.58 & 24.58 & 24.58 \\
\hline SD time, hours & 1.09 & 1.09 & 1.09 \\
\hline SD speed, km per hour & 7.39 & 7.39 & 7.39 \\
\hline Median length, km & 53.38 & 53.38 & 53.38 \\
\hline Median time, hours & 1.59 & 1.59 & 1.59 \\
\hline Median speed, km per hour & 33.11 & 33.11 & 33.11 \\
\hline \multicolumn{4}{|c|}{ Barriers } \\
\hline Mean length, km & 54.61 & 52.90 & 53.75 \\
\hline Mean time, hours & 2.08 & 2.02 & 2.05 \\
\hline Mean speed, km per hour & 31.12 & 31.28 & 31.20 \\
\hline SD length, km & 24.24 & 23.40 & 23.82 \\
\hline SD time, hours & 1.21 & 1.21 & 1.21 \\
\hline SD speed, $\mathrm{km}$ per hour & 7.69 & 7.05 & 7.37 \\
\hline Median length, $\mathrm{km}$ & 51.21 & 49.48 & 50.34 \\
\hline Median time, hours & 1.58 & 1.5 & 1.54 \\
\hline Median speed, $\mathrm{km}$ per hour & 32.04 & 30.78 & 31.41 \\
\hline
\end{tabular}

Table 4. Differences in no-barriers and barriers scenarios.

\begin{tabular}{cccc}
\hline Scenario & $\begin{array}{c}\text { No-Barriers } \\
(246,584 \text { pixels })\end{array}$ & $\begin{array}{c}\text { Barriers } \\
(195,251 \text { pixels })\end{array}$ & $\begin{array}{c}\text { Changed pixels } \\
(51,333 \text { pixels })\end{array}$ \\
\hline$\leq 1$ hour & $59,903 /$ & $52,377 /$ & $-7526 /$ \\
$1-2$ & $20.2 \%$ & $17.6 \%$ & $-2.6 \%$ \\
& $93,343 /$ & $70,335 /$ & $-23,008 /$ \\
$2-3$ & $31.4 \%$ & $23.7 \%$ & $-7.7 \%$ \\
& $52,768 /$ & $38,513 /$ & $14,255 /$ \\
More than 3 hours & $17.8 \%$ & $13.0 \%$ & $-4.8 \%$ \\
& $40,570 /$ & $34,026 /$ & $-6544 /$ \\
No access pixels & $13.7 \%$ & $11.5 \%$ & $51,333 /$ \\
Total "forested" & $50,145 /$ & $101,478 /$ & $+17.3 \%$ \\
pixels & $16.9 \%$ & $34.2 \%$ & \\
\hline
\end{tabular}




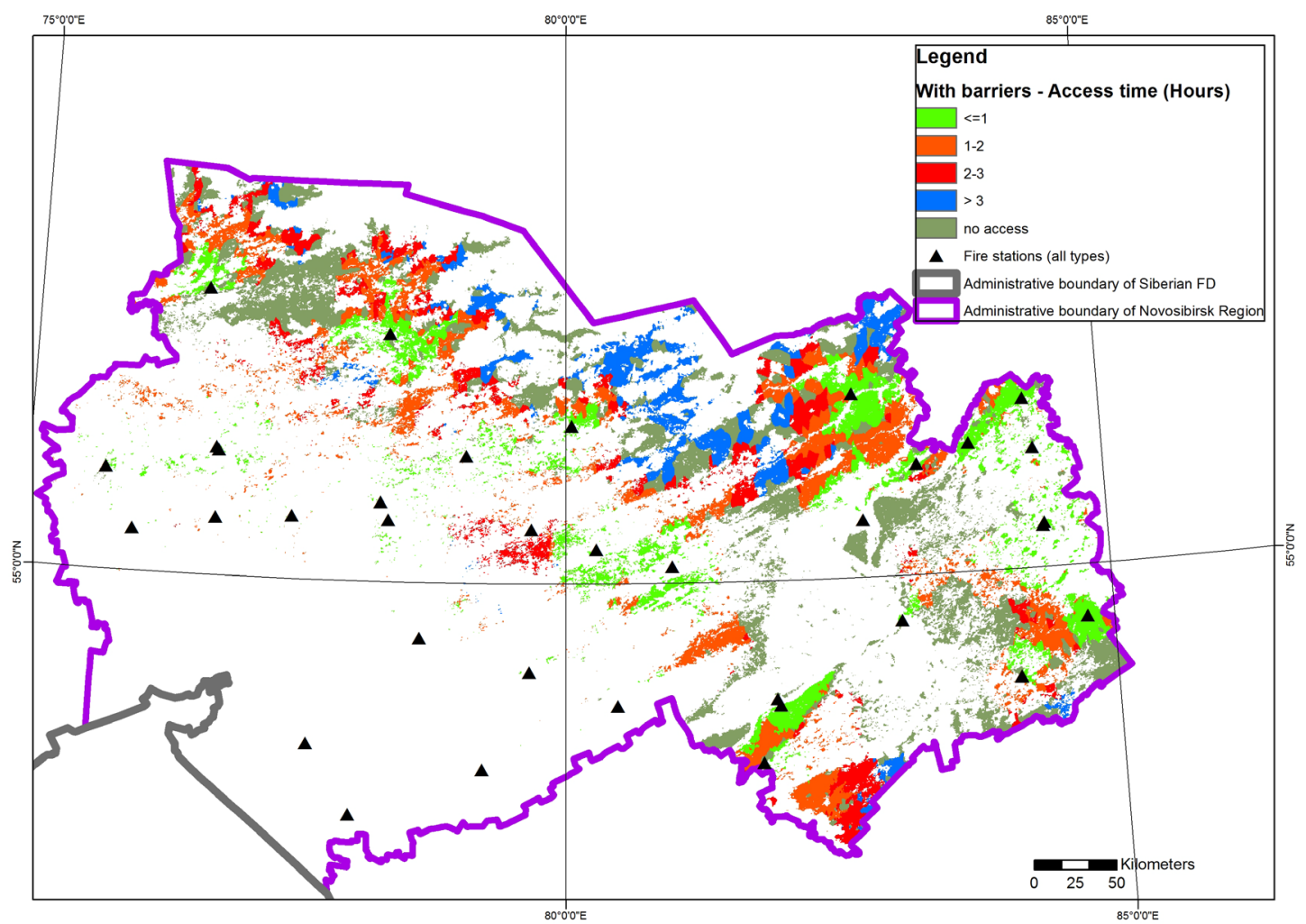

(a)

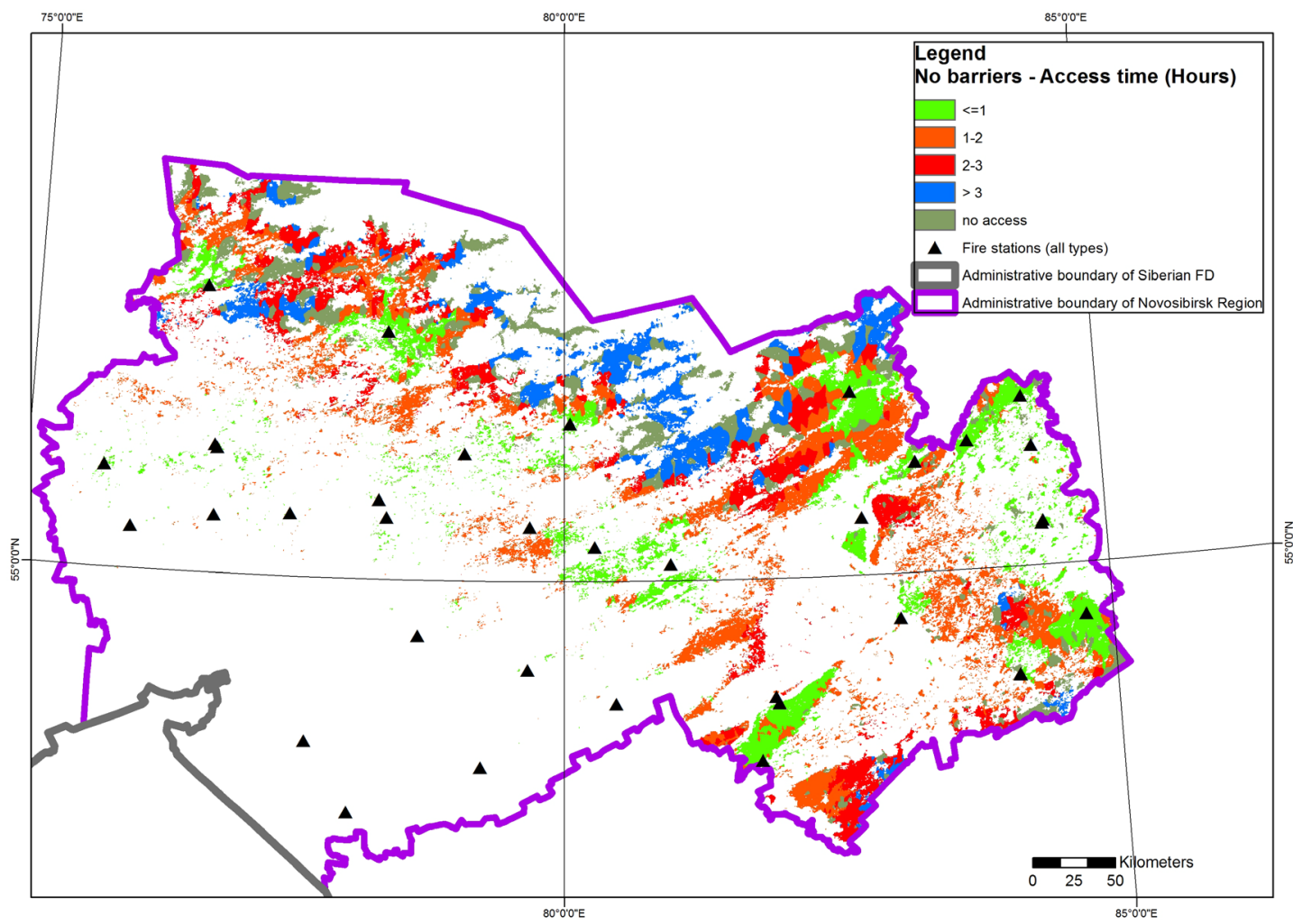

(b)

Figure 8. Transport accessibility of forest resources in Novosibirsk Region. No-Barriers (a) and Barriers (b) scenarios classified by time, in hours. 
Table 4, another important result, gave the detailed analysis for the access time categories 1-2-3 and more hours and thanks to this classification we have shown that number of forest pixels that are no longer accessible in barriers scenario was more than doubled. In the conditions of high and extreme fire burn the situation may turn out to a serious challenge, since it requires an operational decision at the level of the region's forestry department to transfer the forces and resources from one forestry to another one. A useful solution can be to carry out a forest zoning around the fire stations taking into account time as a main criteria of access effectiveness.

Configuration and condition of roads and forest glades, number of forest renters, location of stations to collect and to protect the forest resources are the subject to update on the regular basis depending on the geographical location, transport networks and economic development of the study region. So, regular updates are the must for the data we have used in the present research, and we have already published the paper describing some ways to compare present and historic data sources [35]. Forest rules at the regional and federal levels should be monitored and constantly taken into account as well.

\section{Conclusions}

We have presented a GIS-approach to estimate ground transport accessibility of forest resources on the example of one of the regions of the Siberian FD (Novosibirsk Region). Optimality of fire stations' location could be investigated further, but for the present research, they have played the role of starting points with logistical resources like heavy trucks and stuff to manage the logging operations. As we have seen from Figure 8(a) forest management which does not take into account any boundaries (forest of administrative) could be more effective to plan the move of special vehicle, and has to be supported by the mapping products.

Results could be used for the annual preparation for the fire hazardous season in the forest service divisions of the Russian Federation and in the preparation of regional programs "forestry development" and forest plans. Experience of Russian forest legislation of proposed methodology could be extended for other countries.

To continue our research, we could benefit from the variety of Web-services with traffic data that could be connected to the present GIS-project (WMS, for instance) and can be used as the input data to make a barriers mask. So, by doing so we will be progressing from an evaluation of transport accessibility of one thematic task to the development of transport scenario for decision making with the complexity of parameters included. Thus, this methodology for the forest resources' accessibility could be used in different domains and with various data types and sources.

\section{Acknowledgements}

The authors would like to thank the Center for Forest Ecology and Productivity 
of the Russian Academy of Sciences (CFEP RAS) for supporting their research by the state funding contract "Methodological approaches to estimate structural organization and functioning of forest ecosystems" (topic $\mathrm{N}$

AAAA-A18-118052590019-7).

\section{Conflicts of Interest}

The authors declare no conflicts of interest regarding the publication of this paper.

\section{References}

[1] Efremov, M.A. (2009) Forests Transport Accessibility as a Main Factor to Use the Forest Resources. Bulletin of Volga State University of Technology, 1, 60-65.

[2] Akay, A.E., Wing, G.M., Sivrikaya, F. and Sakar, D. (2012) A GIS-Based Decision Support System for Determining the Shortest and Safest Route to Forest Fires: A Case Study in Mediterranean Region of Turkey. Environmental Monitoring and Assessment, 184, 1391-1407. https://doi.org/10.1007/s10661-011-2049-Z

[3] Dubovik, V.O. (2013) Methods to Estimate Transport Accessibility of Territory. Regional Researches, 4, 11-18. https://www.elibrary.ru/item.asp?id=21118992

[4] Yakusheva, T.V. (2014) Complex Assessment of Forest Resources Availability Taking into Account the Development of Forest Transport Infrastructure within in the North-West (Severo-Zapadnuy) Federal District of Russia. IVUZ Forest Journal, 5, 113-117.

[5] Tretiakov, A.G. (2015) Economical Accessibility of Forest Resources and Transport Logistics. Bulletin of Petrozavodsk State Technical University, 2, 63-69.

[6] Loidl, M., Wallentin, G., Cyganski, R., Graser, A., Scholz, J. and Haslauer, E. (2016) GIS and Transport Modeling-Strengthening the Spatial Perspective. ISPRS International Journal of Geo-Information, 5, 84. https://doi.org/10.3390/ijgi5060084

[7] Martunyuk, A.A., Sidorenkov, V.M., Doroshenkova, E.V., Sidorenkova, E.M. and Zakharov, Y.G. (2016) Differentiation of Russian Federation on the Intensity of Forest Management and Use. Siberian Forest Journal, 1, 3-12.

[8] Duka, A., Grigolato, S., Papa, I., Pentek, T. and Porsinsky, T. (2017) Assessment of Timber Extraction Distance and Skid Road Network in Steep Karst Terrain. iForest-Biogeosciences and Forestry,10, 886-894. https://doi.org/10.3832/ifor2471-010

[9] Malladi, T. and Sowlati, T. (2017) Optimization of Operational Level Transportation Planning in Forestry: A Review. International Journal of Forest Engineering, 28, 198-210. https://doi.org/10.1080/14942119.2017.1362825

[10] Semyagin, I.N. and Khadiullina, G.N. (2018) Methodology to the Complex Estimation of Transport Accessibility for the Privolzhskiy Federal District of Russia. Horizons of Economics, 2, 81-88. https://www.elibrary.ru/item.asp?id=35161208

[11] Akay, A.E., Karas, I.R. and Kahraman, I. (2018) Determining the Locations of Potential Firefighting Teams by Using GIS Techniques. The International Archives of the Photogrammetry, Remote Sensing and Spatial Information Sciences, XLII-4/W9, 83-88. https://doi.org/10.5194/isprs-archives-XLII-4-W9-83-2018

[12] Akay, A.E. (2019) Analyzing the Effects of Logging Truck Sizes on Transportation Costs of Forest Products. V. Science Technology and Innovation Congress, Alanya, 17-21 April, 29-36. 
[13] Chen, X. and Jia, P. (2019) A Comparative Analysis of Accessibility Measures by the Two-Step Floating Catchment Area (2SFCA) Method. International Journal of Geographical Information Science, 33, 1739-1758. https://doi.org/10.1080/13658816.2019.1591415

[14] Ibisch, P.L., Blumroeder, J.S., Hobson, P.R. and Hauck, M. (2019) Ecosystemic Solutions Needed in Forest Management under Global Change. Science, 365, 1388.

[15] Lavrinenko, P.A., Romashina, A.A., Stepanov, P.S. and Chistyakov, P.A. (2019) Transport Accessibility as an Indicator of Regional Development. Studies on Russian Economic Development, 30, 694-701. https://doi.org/10.1134/S1075700719060091

[16] Dunn, C.J., Thompson, M.P. and Calkin, D.E. (2017) A Framework for Developing Safe and Effective Large-Fire Response in a New Fire Management Paradigm. Forest Ecology and Management, 404, 184-196. https://doi.org/10.1016/j.foreco.2017.08.039

[17] Ibisch, P.L., Hoffmann, M.T., Kreft, S., Pe'er, G., Kati, V., Biber-Freudenberger, L., Della Sala D.A., Vale, M.M., Hobson, P.R. and Selva, N. (2016) A Global Map of Roadless Areas and Their Conservation Status. Science, 16, 1423-1427. https://doi.org/10.1126/science.aaf7166

[18] Nelson, A. (2008) Estimated Travel Time to the Nearest City of 50,000 or More People in Year 2000. Global Environment Monitoring Unit-Joint Research Centre of the European Commission, Ispra. https://forobs.jrc.ec.europa.eu/products/gam/

[19] Weiss, D., Nelson, A., Gibson, H., et al. (2018) A Global Map of Travel Time to Cities to Assess Inequalities in Accessibility in 2015. Nature, 553, 333-336.

https://doi.org/10.1038/nature25181

[20] Glavatskiy, G.D. (2000) Justification of Criteria to Access the Level of Forest Fire Protection. Forest Bulletin, 3, 87-100.

[21] Glavatskiy, G.D. and Grumans, V.M. (2001) Organization of Large-Scale Forest Fires' Extinguishing in the Multi-Forest Areas of Siberia. Forest Bulletin, 2, 45-55.

[22] Podolskaia, E.S., Ershov, D.V., Kovganko, K.A. and Plotnikova, A.S. (2017) Creation of a GIS-Model to Plan the Optimal Route to Deliver the Technical Means to the Place of Forest Fire. Forests of Russia: Politics, Industry, Science, and Education. Proceedings of the 2nd International Science and Technical Conference, 200-202. https://elibrary.ru/item.asp?id=30620998

[23] Podolskaia, E., Ershov, D. and Kovganko, K. (2018) Modern GIS-Capabilities to Model Ground Access to the Forest Fires. Conference of Center for Forest Ecology and Productivity (CEPF RAS). Scientific Bases of Sustainable Forest Management, 12. http://cepl.rssi.ru/wp-content/uploads/2018/11/Podolskaya-E.S.-et.-al..pdf

[24] Podolskaia, E.S., Kovganko, K.K., Ershov, D.V., Shulyak, P.P. and Suchkov, A.I. (2019) Using of Transport Network Model to Estimate Travelling Time and Distance for Ground Access a Forest Fire. Forest Science, 2, 1-24.

http://jfsi.ru/en/2-2-2019-podolskaia_et_al/ https://doi.org/10.31509/2658-607x-2019-2-2-1-22

[25] Podolskaia, E., Ershov, D. and Kovganko, K. (2019) GIS-Analysis of ground Transport Accessibility of Fire Stations at Regional Scale. Abstracts of the International Cartographic Association, 1, 301. https://doi.org/10.5194/ica-abs-1-301-2019

[26] Podolskaia, E.S., Kovganko, K.A. and Ershov, D.V. (2019) Regional Geoinformation Modeling of Ground Access to the Forest Fires in Russia. In: Popovich, V., Thill, J.C., Schrenk, M. and Claramunt, C., Eds., Information Fusion and Intelligent Geographic Information Systems, Advances in Geographic Information Science, Sprin- 
ger, Cham, 155-165. https://doi.org/10.1007/978-3-030-31608-2_11

[27] Bartalev, S.A., Egorov, V.A., Zharko, V.O., Loupian, E.A., Plotnikov, D.E. and Khvostikov, S.A. (2015) Current State and Development Prospects of Satellite Mapping Methods of Russia's Vegetation Cover. Current Problems in Remote Sensing of the Earth from Space, 12, 203-221.

[28] Balashov, I., Bartalev, S., Bartalev, S., Burtsev, M., Vorushilov, I., Egorov, V., Kashnitskii, A., Khovratovich, T., Khvostikov, S., Kobets, D., Loupian, E., Saigin, I., Senko, K., Stytsenko, F., Sychugov, I. and Zharko, V. (2020) Vega-Les Information System. Actual Features and Future Evolution. IOP Conference Series: Earth and Environmental Science, 507, Article ID: 012002.

https://doi.org/10.1088/1755-1315/507/1/012002

[29] Loupian, E.A., Bartalev S.A., Ershov D.V., Kotelnikov R.V., Balashov I.V., Bourtsev M.A., Egorov V.A., Erfemov, V.Y., Zharko, V.O., Kovganko, K.A., Kolbudaev. P.A., Krasheninnikova, Yu. S., Proshin, A.A., Mazurov, A.A., Uvarov, I.A., Stytsenko, F.V., Sychugov, I.G., Flitman, E.V., Khvostikov, S.A. and Shulyak, P.P. (2015) Satellite Data Processing Management in the Forest Fires Remote Monitoring Information System (ISDM-Rosleskhoz) of the Federal Agency for Forestry. Current Problems in Remote Sensing of the Earth from Space, 12, 222-250.

[30] Grigolato, S., Marchi, E., Laschi, A. and Cavalli, R. (2019) Riflessioni sulla viabilita forestale e opere connesse a support delle iniziative per la predisposizione dei decreti attuativi del Testo Unico in materia di Foreste e Filiere Forestali. Forest, 16, 49-55. https://doi.org/10.3832/efor3175-016

[31] Krumov, T. (2019) Determination of the Optimal Density of the Forest Road Network. Journal of Forest Science, 65, 438-444. https://doi.org/10.17221/101/2019-JFS

[32] Laschi, A., Foderi, C., Fabiano, F., Neri, F., Cambi, M., Mariotti, B. and Marchi, E. (2019) Forest Road Planning, Construction and Maintenance to Improve Forest Fire Fighting: A Review. Croatian Journal of Forest Engineering, 40, 207-219.

[33] (1997) Regulations on Fire Stations. Order of Federal Forestry Agency, N167. http://docs.cntd.ru/document/58817250

[34] Forest Law. Article 23. Forestry (Federal Law N 538 from 27/12/2018). http://www.consultant.ru/cons/cgi/online.cgi?req=doc\&base=LAW\&n=314924\&fld $=134 \& \mathrm{dst}=1000000146,0 \& \mathrm{rnd}=0.6644144593549033 \# 012087154036562842$

[35] Podolskaia, E., Ershov, D. and Kovganko K. (2020) Comparison of Data Sources on Transport Infrastructure for the REGIONAL forest Fire Management. Book of $A b$ stracts, Managing Forests in the 21st Century, Potsdam, 3-5 March 2020, 59. 